\title{
MERASAKAN TASAWUF
}

\section{Mukhamad Anieg}

STIQ Islamic Centre Demak

Ahlan042000@yahoo.com

Awareness has inspired humans to feel Sufism. Various kinds of questions lie about mutasawifin, including Who am I? Where am I? For what I created? How do I fill out alive? What am I looking for? What kind of life I want to pick up after death? If I could go back to my native place safely? And other fundamental questions in human beings. Religion deifying vehicle, Iman deifying fuel, and the man who drove, the religion with the contents of the sentences noble in heart, it was the straight path. The way of approaching Him is to continue to multiply zikrullah. Zikir is the parent of worship, then where is the zikir when penetrating into the heart of a clean then it will feel the souls kesufian true. Hearts (qolbu) can also be likened to building a house. He was surrounded by walls and secured with a gate or gate locked. Only family members and guests who comes who may enter it. While the heart of the deeper (lubb) is a locked room that holds valuable heirlooms belonging to the family. Only a few family members who have the key. So when the door was open means opened the doors of Sufism in human beings and to feel the pleasure that can perform worship and all the good deeds that will save people in the world and the hereafter.

Keyword: Sufism, qolbu, zikir 


\section{A. Pendahuluan}

Manusia dilahirkan adalah untuk mengenal Tuhannya. Kemampuan ini adalah sebagai sebuah potensi yang sama pada seluruh manusia, dan potensi ini pun juga sudah menjadi fitrahnya. Oleh karena itu sudah menjadi pembawaan secara intrinsik, maka kecenderungan berketuhanan (hablum minallah) ini tidak bisa dielakkan oleh siapapun. ${ }^{1}$

Kecenderungan rasa cinta kepada Allah sebagai realitas mutlak dan absolut ini, diekspresikan oleh sebagian orang dengan melakukan perbuatan dalam bentuk ibadah formal seperti doa, shalat, puasa, haji dan ibadah syariah lainnya. Ekspresi ini lebih dikenal dengan figh. Sementara sebagian yang lain melaksanakan lebih dari sekedar ibadah formal yakni bertaqorrub kepada Allah sedekat-dekatnya penuh cinta bahkan bersatu dengan-Nya. Ekspresi yang kedua inilah yang kemudian disebut dengan tasawuf (mistisisme / mistyc). Dengan demikian terlihat bahwa objek kajian tasawuf lebih mengarah pada kajian yang bersifat batiniyah (esoteris), sedangkan fiqh lebih menekankan pada aspek-aspek luar (eksoteris). Keunikan tasawuf yang bersifat esoteris ini menyebabkan ia lebih bersifat universal, luas, lentur dan inklusif.

Esoterisme tasawuf terlihat nyata karena perbincangan yang muncul didalamnya senantiasa mengarah pada aspek ruhani yakni penyucian jiwa (tazkiyah an-nafs) untuk selanjutnya melakukan perjalanan menuju Allah. Pengalaman kerohanian ini biasanya di ukur dengan rasa (dzawq) yang tentu saja sangat bersifat personal karena setiap individu merasakan pengalaman yang dipastikan tidak akan pernah sama dengan yang lain. Pengalaman ini juga meniscayakan keragaman yang tak mungkin disatukan sebab hal ini terkait erat dengan kondisi kejiwaan seseorang, tingkat pemahaman, keyakinan, penghayatan dan perolehannya dari pemberian (mauhibah, jamaknya mawahib) Allah Sang Maha Pengasih.

Dalam menjalani hubungan dengan Allah tentu ada bedanya antara orang yang melakukan riyadhah (dzikir, puasa, shalat, qiyamul lail, shadaqah) yang berangkat dari merasakan kecintaan kepada Ilahi dengan yang berangkat dari ketakutan kasus korupsinya ketika diselidiki oleh kejaksaan, atau seseorang yang terjangkit penyakit sedangkan sakitnya tak kunjung sembuh, atau bisnismen yang upaya bisnisnya mengalami kemacetan, atau pejabat karena pangkat dan karirnya yang tersendat, atau politikus yang selalu serakah ingin menang pemilu/pilkada, atau pendekar yang rakus akan kesaktian dan lain-lain.

Peran tasawuf disini tidak mengajarkan orang malas berikhtiar untuk sukses dalam usaha dan aktifitasnya, dengan menempuh jalan pintas yang tidak rasional namun penuh keajaiban. Tasawuf tidak mengajak orang untuk berbincang tentang karomah atau kekuatan-kekuatan supranatural untuk dapat menaklukkan orang lain, tasawuf tak menghambat orang untuk mengejar pengetahuan demi keluasan wawasan dan pemanfaatan teknologi. Karenanya tasawuf terbuka terhadap pertanyaan-pertanyaan kritis dan rasional serta tidak menyembunyikan ajaran-ajarannya dibalik 'pamali(istilah sunda), ora elok(istilah jawa), tabu, dan indoktrinasi. Sesungguhnya memang tasawuf seperti inilah yang didambakan dunia. Tapi sayangnya banyak juga orang-orang ahli tasawuf yang membawakan dakwah tasawuf dengan gaya klenik,

1 Rudolf Otto, The Psychology of Religion, New York: McMillan, 1967, hlm. 80 
menjajakan karomah untuk imbalan yang murah, menjanjikan sukses dengan jalan pintas. Ada yang membincangkan hakikat sambil mengepul-ngepulkan asap rokok (sebuah tindakan yang tidak mulia bagi dunia islami yang semakin sadar akan kesehatan diri dan kelestarian lingkungan). Rajin dzikir tapi malas belajar dan tidak menunjukkan prestasi kerja.

\section{B. Arti Merasakan Tasawuf}

Bila kita bertanya tentang apa itu merasakan tasawuf. Bahwa merasakan tasawuf yaitu merasakan ketulusan kepada Allah dengan penuh cinta dan kerinduan dan pergaulan yang baik sesama manusia. Setiap orang yang cinta tulus kepada Allah dan membaguskan pergaulannya dengan sesama manusia bisa dikatakan dia sudah merasakan kesufian. Ketulusan kepada Allah berarti menghilangkan kepentingan-kepentingan keegoisan diri untuk melaksanakan perintah Allah. Sementara pergaulan yang baik antar sesama manusia adalah tidak mengutamakan keinginannya di atas keinginan manusia yang lain, selama keinginan mereka itu sesuai dengan syari'at. Sebab, setiap orang yang rela terhadap penyimpangan syari' at dan mengingkarinya, dia bukanlah sufi. Jika dia mengaku seorang sufi, berarti dia telah berdusta atas kebenaran nilai-nilai kesufiannya. ${ }^{2}$

Allah memberikan benih-benih Iman didalam qolbun manusia, naluri ber-Tuhan yang membawa orang untuk selalu tertarik mencintai, mencari, meneliti, menjelajah, mencoba mengenali Allah. Karena itu di dalam semua budaya, bahkan semua lingkungan, orang akan percaya akan adanya Tuhan yaitu adanya Dia yang misterius itu. Meskipun ada yang tidak percaya pun sangat sedikit jumlahnya itupun mereka yang benar-benar tersesat. Lalu manusiamanusia itu memberi nama / istilah-istilah kepada apa yang disebut Tuhan. Maka muncullah 'Tuhan' dengan berbagai bahasa, sedangkan untuk mengenalnya pertama kali haruslah dengan sentuhan "rasa" yaitu "rasa kehambaan".

Bertasawuf menganugerahkan manusia dapat merasakan dirinya sebagai makhluknya Allah. Manusia harus menyadari atau mengetahui secara mendasar bahwa ia adalah makhluk (yang diciptakan) sedangkan Allah sebagai Khaliq (Pencipta, Allah). Misal untuk menggambarkan lebih mudah dapat kita kaitkan dengan pertanyaan "Mengapa kita melakukan shalat?", karena, selain itu sebagai perintah Allah, dalam shalat kita juga mengetahui (márifat) bahwa diri kita makhluk yang selalu menyembah dan bersujud kepada-Nya. Sudah menjadi kewajiban makhluk untuk menyembah, mengabdi, dan tunduk kepada penciptaan-Nya. Inti shalat adalah do'a. Jadi, orang yang berdo'a kepada Allah menyadari bahwa dirinya makhluk, yang lemah dan butuh pertolongan serta lindungan dari Allah, sebagai Dzat Yang Maha Memberi pertolongan dan perlindungan. Sedangkan Allah yang di mintai do'a adalah sebagai Kholik (Sang Pencipta)

Manusia memiliki sifat lalai (ghaflah) yang akan mengganggu ibadah dan amal-amal saleh lainnya. Maka shalat dan ibadah lainnya, seperti wirid dan dzikir, serta latihan lainnya, bertujuan untuk terus mengingatkan manusia akan hakikat dirinya, sebagai makhluk, yang diciptakan oleh Khaliq. Dengan begitu, semua ibadah yang dilakukan akan dilaksanakan dengan ikhlas.

2 Imam al-Ghazali, Risalah-Risalah Al-Ghazali, Bandung: Pustaka Hidayah, 1997, hlm. 33 
Lillahi ta’ala, hanya karena Allah Tảala. Bukan karena alasan untuk harta benda, kekuasaan, atau kepentingan duniawi lainnya.

Jalan utama menuju kebersihan jiwa dan kesucian hati ini, adalah sebuah proses yang disebut dengan "Ibadah-ibadah hati" atau dengan kata lain ibadah-ibadah yang di lakukan seseorang dengan hatinya. Meskipun ibadah-ibadah zahir juga sangat penting dan menentukan bagi keselamatan manusia di dunia dan di akherat, namun demikian "ibadah-ibadah hati" lebih menentuka lagi, karena ibadah-ibadah zahir tersebut walau sudah terpenuhi syarat dan rukunnya secara sempurna, tetap tidak akan diterima oleh Allah jika tidak dibangun diatas ibadah hati yang benar dan sempurna. Sebagai contoh: shalat yang dilaksanakan dengan syarat dan rukun yang sempurna tidak akan diterima jika dilakukan tanpa keiikhlasan yang sempurna karena Allah.

Apabila hamba Allah sebelumnya telah melakukan Dzikir Jahri (yaitu dzikir dengan suara) dengan ikhlas maka pada saat Dzikir Sirri di qolbu akan muncul beberapa rasa yaitu:

a. Rasa terbakar, kehangatan yang menjalar dari api cinta dan rindu kepada Allah SWT.

b. Rasa tenggelam, terhanyut dalam lautan rahmat Allah SWT, terengkuh dalam pelukan qudrat-Nya dan tertimang dalam buaian iradat-Nya.

c. Rasa terguncang, terguncangnya jiwa dan raga oleh getaran qalbu yang berdzikir mengingat Allah (QS. Al-Anfal 8:2).

d. Puncaknya adalah air mata kebahagiaan yang mengalir dari taman taqwa di dalam qalbu.

Firman Allah,

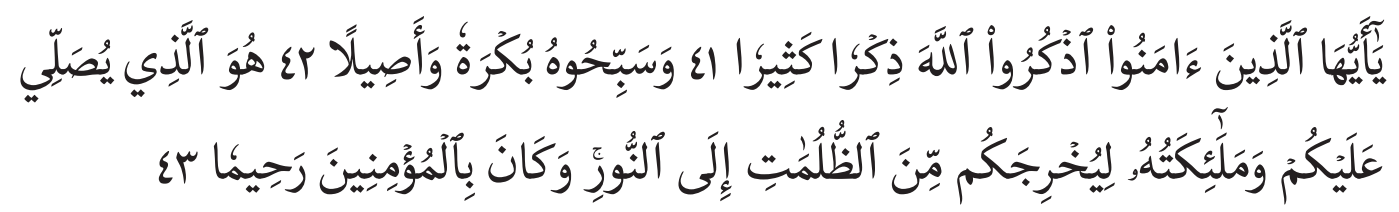

Artinya: "Hai orang-orang yang beriman, berdzikirlah (dengan menyebut nama) Allah, dzikir yang sebanyak-banyaknya dan bertasbihlah kepada-Nya di waktu pagi dan petang. Dialah yang memberi rahmat kepadamu dan malaikat-Nya (memohon ampunan untukmu), supaya Dia mengeluarkan kamu dari kegelapan kepada cahaya (yang terang). Dan adalah Dia yang Maha Penyayang kepada orang-orang yang beriman" (QS. Al Abzab:41-43)

\section{Komponen Rohani Manusia Sebagai Makhluk Allah}

Manusia hidup dibangun atas tubuhnya, diantara rangkaian komponen rohani manusia adalah hati, jiwa, nafs dan akal budi Untuk mengetahui dan membedakan keempat istilah ini adalah sangat penting. Sebab pembahasan keempat masalah ini dapat dikatakan sangat jarang bahkan terkadang menjadi rancu. Penjelasan mengenai keempat istilah ini umumnya mengacu pada penjelasan Said Hawa dalam bab "penjelasan makna jiwa, ruh, hati dan akal pikiran" dari tulisan-tulisan buah karyanya yang termaktub dalam sebuah buku tasawuf. 
Hati, jiwa, ruh dan akal budi, sebagaimana disebut Sa’id Hawa, terkadang bisa bermakna tunggal. Nama-nama tersebut dapat berubah karena perubahan ruh manusia yang bermacammacam. Apabila nafsu syahwat dapat mengalahkan ruh, maka ia disebut hawa nafsu (diri rendah menurut istilah Frager). Jika ruh dapat mengalahkan syahwat, ia disebut akal, sedangkan jika penyebabnya adalah rasa keimanan, ia disebut hati. Dan apabila ia mengenal Allah dengan seebenar-benarnya dan melakukan ibadah dengan tulus, maka ia disebut ruh. ${ }^{3}$ Adapun penjelasannya sebagai berikut

\section{Al-Qolbu (Hati)}

Qalbu merupakan pimpinan mutlak bagi seluruh tubuh. Ia adalah organ halus yang dapat menerima sinyal-sinyal ketuhanan, dan yang paling penting berkaitan dengan pembahasan manajemen qolbu seperti dikatakan Sa'id Hawa, ia adalah pusat garapan pendidikan Islam karena ia merupakan lokus ingatan dan pemahaman. qolbu adalah sumber dimana realitasrealitas dapat dimengerti dan dipahami. ${ }^{4}$

\section{Al-Ruh}

Istilah ruh sebagaimana juga qolbu, merujuk pada dua makna. Makna pertama adalah jisim atau jasad halus yang bersumber dari rongga hati jasmani. Ia tersebar ke seluruh bagian tubuh dengan perantara urat nadi, dan juga tersebar ke aliran-aliran darah dalam tubuh serta ke aliran sumber hidup, sember instink, sumber penglihatan, sumber pendengaran, dan sumber penciuman menuju organnya masing-masing. Ia sama dengan aliran cahaya pelita yang menerangi setiap sisi rumah, sehingga tidak ada bagian rumah yang tidak mendapatkan cahayanya.

Seperti halnya demikianlah hidup ini. Ia sama dengan cahaya yang liputannya menyebar luas, ruh sama dengan pelita. Aliran dan gerakan ruh dalam batin sama dengan aliran atau perambatan cahaya pelita yang terdapat di setiap sisi rumah dengan bahan pembakarannya yang terbakar. Para dokter menyebut ruh sebagai uap yang sangat halus yang bisa mematangkan panasnya hati. ${ }^{5}$

Pendapat yang lain Ruh (nyawa) dalam arti jasmani. Roh adalah tubuh halus (jismun lathifun) yang bertempat tinggal di kepala. Sumbernya adalah lubang hati yang bertubuh, lalu tersebar dengan perantaraan urat-urat nadi dan darah yang memanjang ke segala bagian tubuh yang lain dan mengalir ke dalam tubuh, dengan meancarkan cahaya ke seluruh tubuh manusia. ${ }^{6}$

Makna kedua, adalah perasaan halus (lathifah) manusia yang mengetahui dan mengerti. Ia merupakan perkara dan urusan yang luar biasa, hingga kebanyakan akal dan pemahaman manusia tidak mampu menangkap hakikatnya. Inilah maksud firman Allah : "Katakanlah, ruh itu termasuk urusan Tuhanku. (Q.S. al-Isra' :85).

\footnotetext{
3 Said Hawa, Jalan Ruhani, cet. Ke-4, Bandung: Mizan, 1996, hlm. 48

4 Said Hawa, Jalan Ruhani, cet. Ke-4, Bandung: Mizan, 1996, hlm. 44

5 Said Hawa, Jalan Ruhani, cet. Ke-4, Bandung: Mizan, 1996, hlm. 45

6 Amin Syukur dan Fatimah Usman, Insan Kamil Kontemporer (Paket Pelatihan Seni Menata Hati (SMHI), CV. , Semarang: Bima Sejati, 2004, hlm. 14
} 


\section{3. al-Nafs (Diri, Ego)}

Nafs memiliki banyak konotasi makna. Namun secara garis besar ia dapat digolongkan menjadi dua makna, yaitu: pertama, cakupan makna dari kekuatan amarah dan syahwat (birahi) dalam diri manusia. Pengertian inilah yang sering digunakan oleh para ahli tasawuf, karena maksud al-nafs menurut mereka adalah dasar cakupan sifat-sifat tercela dari manusia. Hal ini didasarkan pada sebuah sabda Nabi : "Musuhmu yang paling besar adalah nafsumu yang ada di antara kedua lambungmu”. (H.R. Baihaqi).

Makna kedua, perasaan halus yang menjadi hakekat manusia. Ia adalah jiwa manusia dan hakikatnya, hanya saja nafs ini dapat berwujud multi dimensi, tergantung keadaan. Mana kala ia masih terkendali, maka ia disebut an-nafs al-muthmäinnah (jiwa yang tenteram) seperti firman Allah : "Wahai jiwa yang tenteram, kembalilah kepada Tuhanmu dengan hati yang puas lagi diridlai-Nya”. (QS. Al-Fajr: 27-28).

Bila nafs itu belum sempurna, namun tetap menyerang dan membuka front dengan hawa nafsu, maka nafs yang demikian disebut dengan an-nafs al-lawwamah (jiwa yang menyesali dirinya sendiri). Sebab nafs tersebut mencerca pemiliknya ketika dia melalaikan pengabdian kepada Tuhannya. "Dan aku bersumpah dengan jiwa yang amat menyesali (dirinya sendiri)" (Q. S. Al-Qiyamah: 2).

Namun bila nafs telah menjauhi pertentangan, tunduk dan taat pada kehendak hawa nafsu dan godaan-godaan setan, nafs itu dinamakan an-nafs al-ammarah bi al-su' (nafsu yang menyerah pada kejahatan). Allah SWT. berfirman menceritakan istri Al-Aziz: Dan aku tidak membebaskan diku dari kesalahan, karena sesungguhnya nafsu itu selalu menyuruh kepada kejahatan. (QS. Yusuf: 53).

\section{Akal Budi}

Kadang kala istilah akal dimaksudkan pada ilmu tentang hakikat segala sesuatu, dan ini adalah sifat dari ilmu yang terdapat di dalam hati. Terkadang juga ia dimaksudkan pada ilmu yang mengetahui segala ilmu. Yakni hati yang memiliki perasaan halus. Sebagaimana diketahui, setiap orang yang berilmu memiliki sebuah wujud di dalam dirinya sendiri yang independen. Ilmu adalah sifat yang menempati sebuah wujud tersebut dan merupakan sifat yang tiada tersifati. Sedangkan akal adalah sifat orang yang berilmu, atau biasa juga diartikan sebagai tempat pengetahuan. ${ }^{7}$

Dalam istilah-istilah keislaman sering dijumpai istilah akal taklifi dan akal syar'i. Akal jenis pertama dimiliki setiap manusia selama dia tidak gila. Akal tingkat ini adalah tingkatan terrendah yang dimiliki oleh seorang mukallaf dan nantinya akan dimintai pertanggungjawaban. Jenis yang kedua adalah akal syar'i. Akal jenis ini bertempat di dalam hati serta memiliki tingkatantingkatan. Manifestasi akal ini yang paling sempurna adalah pengekangan terhadap nafsunya berdasarkan perintah Allah, disamping penyerahan dan pengenalan terhadap-Nya.

Ibn Sina mengembangkan ajaran tentang jiwa yang baginya ada tiga bagian: jiwa tumbuh- 
tumbuhan (al-nafs al-nabatiyah), jiwa binatang (al-nafs al-hayawaniyah), dan jiwa manusia (alnafs al-nathiqah). Jiwa manusia mempunyai dua daya:

a. Praktis (al-'amilah, practical) yang hubungannya dengan badan.

b. Teoretis (al-'alimah atau al-nazhariah, theoretical) yang hubungannya dengan hal-hal abstrak. Daya ini mempunyai tingkatan:

1) Akal materiil (al-'aql al-hayulani, material intellect) yang semata-mata mempunyai potensi berfikir dan belum dilatih.

2) Intellectusin habitu (al-aqlbial-malakah) yang telah dilatih berfikir tentang hal-hal abstrak.

3) Akal Mustafad (al-'aql al-mustafad, acquired intellect) yaitu akal telah terlatih dan mengetahui hal-hal abstrak. Akal seperti inilah yang dilimpahi ilmu oleh Akal Aktif (al'aqlal-fa'al)

Bagi Ibn Sina, akal mempunyai empat tingkat dan yang terendah di antaranya adalah al-'aql al-hayulani (akal materiil). Adakalanya Tuhan menganugerahkan kepada manusia akal materiil yang besar lagi kuat yang oleh Ibn Sina diberi nama al-hads yaitu intuisi. Daya yang ada pada akal materiil seperti ini begitu besarnya, sehingga tanpa latihan, mudah dapat berhubungan dengan Akal Aktif dan dengan mudah dapat menerima cahaya atau wahyu dari Tuhan. Akal seperti ini mempunyai daya suci (quwwah qudsiyyah). Inilah akal tertinggi yang dapat diperoleh manusia, dan terdapat hanya pada nabi-nabi. ${ }^{8}$

Kemampuan manusia untuk mencapai derajat ma'rifatullah dengan hatinya yang bersih dalam hal ini bagaikan kemampuan manusia untuk menghancurkan benda-benda keras dengan pukulan "tenaga dalamnya". Dalam keadaan normal manusia memang mustahil dapat melakukan hal-hal semacam itu. Akan tetapi hal itu secara empiris bisa bahkan seringkali terjadi, setelah ia dapat melatih diri sehingga potensi yang memang sesungguhnya dimiliki setiap orang itu berhasil ia peroleh dengan melakukan latihan-latihan tertentu. Dari sini terkadang akal seseorang tidaklah mampu untuk merasionalkan dan menelusuri keajaiban kekuatan hati itu. Sehingga akan muncul pertanyaan;

\section{Apa Hubungan Qolbu dengan Rasio?}

Imam Al-Ghazali pada suatu kesempatan dia menyatakan bahwa hubungan antara hati dan rasio itu seperti telaga. Telaga mendapatkan air dari dua sumber. Sumber pertama adalah mata air, dan sumber kedua adalah sungai. Bagaimana caranya supaya kita mendapatkan air yang jernih dan berlimpah? Caranya adalah dengan cara memotong aliran sungai itu. Dengan membendung aliran sungai maka akan terjadi dua hal: (1) mata air ini akan memancarkan air lebih banyak, karena tidak ada tekanan dari sungai; (2) airnya dijamin akan lebih jernih, karena tak seperti dari mata air biasa, yaitu air yang datang dari sungai tidak tercampur bermacam-macam kotoran. Kalau aliran sungai dibendung, akan didapatkan air yang berlimpah dan lebih jernih. Kata Imam Al-Ghazali, mata air ini menyimbulkan hati dan sungai adalah saluran akal (rasio). Kalau kita ingin mendapatkan hati yang lebih bening, maka rasio harus kita tutup. Meski barang kali Al-Ghazali memaksudkan rasio ini dilakukan pada tahap lanjut proses berpikir - yang pada 
awalnya diyakini tetap membutuhkan prosedur rasional - ungkapan-ungkapan seperti ini bisa menimbulkan kesalahpahaman yang mengambil bentuk kesan antirasional tasawuf.

Dalam kitab tersebut yaitu Munqidz min Al-Dhalal (Pembebas dari Kesesatan), dia juga menyatakan ketidakmungkinan pengungkapan tasawuf (secara rasional). Katanya, berusaha mengungkapkan tasawuf secara rasional adalah bagaikan berusaha mengungkapkan rasa apel kepada orang yang belum pernah merasakannya. Atau, masih dalam metafora yang diajukannya, seperti mengungkapkan pengalaman (kenikmatan) hubungan seks kepada bujang atau lelaki yang impoten. Dengan kata lain, tidak mungkin. ${ }^{?}$

Di dalam Al-Quran, menurut saya, tidak bisa diperoleh pemahaman yang menghadapkan akal dan hati secara berlawan-lawanan. Dalam Al-Quran, 'kebetulan' istilah 'akal' dalam bentuk kata benda verbal (mashdar) tidak bisa ditemukan. Yang ada adalah bentuk kata kerjanya, yaitu ya'qilun (proses berpikir dengan menggunakan akal). Ketika Al-Quran menyebut alat yang dipakai untuk ya'qilun, maka yang dirujuk bukanlah akal ('aql) melainkan qolbu (hati). Khususnya dalam bentuk fu'ad, hati yang telah mencapai tingkat kestabilan. Jadi, dalam ALQuran dalam konsep Islam, akal itu adalah hati, dan hati itu adalah akal. Wa-Allahua'lam

\section{Qolbu yang bersih alat merasakan tasawuf}

Spiritualitas manusia berpusat pada qolbu, dan di dalam qolbu manusia sudah ada potensipotensi rasa spiritual yang merupakan format dasar kemanusiaan. Maka kalau saja manusia selalu mengikuti suara qolbunya yang bersih dan benar, maka akan dapat menyelamatkan diri dan kehidupannya dan juga akan menenangkan diri serta membawa diri kepada kehidupan yang istiqomah.

Berkata Wabishah Al-Asadi, "Aku datang kepada Rasulullah SAW dan aku tidak akan mengesampingkan barang sedikitpun tentang kebajikan dan dosa melainkan mesti akan kutanyakan kepada beliau, dan beliau saat itu dikelilingi sejumlah kaum muslim untuk meminta nasehat dan aku pun melangkah melewati mereka, dan mereka berkata, "hai Wabishah, jangan dekat Rasulullah SAW!” Aku katakan, “Biarkanlah aku! Aku akan mendekat kepada beliau. Karena beliau adalah orang yang paling aku cintai untuk saya dekati." Beliau (Nabi) bersabda, "Biarkanlah Wabishah! Kemari, Wabishah! (dua atau tiga kali)" Kata Wabishah," Akupun mendekat kepada beliau hingga aku duduk bersimpuh dihadapannya". Lalu beliau bersabda," Hai Wabishah, apakah kau mau aku beritahu atau engkau akan bertanya kepadaku?” Aku berkata,"Tidak, melainkan beritahulah aku. Beliau bersabda, "Engkau datang untuk bertanya kepadaku tentang kebajikan dan dosa bukan?” Wabishah menjawab,”Ya!" lalu beliau merapatkan jari-jari beliau, kemudian dengan jari-jari itu beliau menepuk dadaku dan bersabda: "Hai Wabishah, mintalah fatwa (bertanyalah, berkonsultasilah) kepada hatimu! Mintalah fatwa kepada dirimu! (tiga kali), kebajikan ialah sesuatu yang hati merasa tentram kepadanya dan dosa ialah sesuatu yang terbetik di dalam hatimu dan bergejolak dalam dada, sekalipun orang banyak memberi fatwa (membenarkan) kepadamu, sekalipun mereka memberi fatwa kepadamu!". (HR. Bukhori).

9 Imam al-Ghazali, Munqidz min al-Dlalal, dalam Majmuah Rasail, Beirut: Dar al-Fikr, 1996, hlm. 62 
Masalahnya sekarang adalah qolbu manusia sering lengah dan lalai sehingga mudah terdorong untuk berbuat hal-hal yang sesat ketika dipengaruhi oleh gejolak hawa nafsu dan terseret oleh godaan iblis/setan. Untuk itulah Allah SWT menurunkan para rasul dengan membawa ajaran agama sebagai pengingat bagi yang lengah, petunjuk bagi yang bingung, penegas bagi yang ragu. Sumber ilmu (informasi) keagamaan adalah kitab suci, tapi faktor utama dalam proses keberagamaan adalah qolbu. Dalam proses hidup beragama kitab suci adalah faktor sekunder. AlQur'an pun banyak mengarahkan manusia untuk selalu mendengarkan suara atau bisikan yang bersih dari qalbunya. Sehingga dapat diikuti dengan amal-amal saleh yang akan mengantarkan ke surga.

Hakekat diri manusia adalah diri yang berwujud ruhaniah/spiritual yang sudah tercipta sebelum adanya tubuh biologis (basyar). Ketika manusia masih dalam wujud ruh di alam lahut, ruh merupakan wujud pertama manusia dalam proses penciptaannya sebelum diturunkan ke bumi dan dimasukkan ke dalam tubuh jasmaniah (basyar). Sampai akhirnya Allah meniupkan ruh kejasad manusia sehingga sempurnalah manusia sebagai makhluk-Nya. Allah mempersiapkan basyar (tubuh biologis kebinatangan) hanya sebagai cangkang/wadah bagi manusia itu sendiri untuk hidup dan berkembang di bumi.

Inti ruh yang menjadi pusat diri manusia adalah qolbu. Di dalam Bahasa Arab dikenal ada 2 macam qalbu;

Qolbu jasmaniab yaitu yang berupa gumpalan daging yang berada didalam dada manusia.

Qolbu rubaniahyang dalam Bahasa Indonesia disebut hati nurani. Di dalam qalbu ruhaniah inilah terletak fithrah (sifat-sifat asli dari Tuhan) berupa kesadaran, perasaan, kecerdasan, iman dan iradah. Jadi, sejak diturunkan dari sisi Allah, si manusia ruhaniah itu qolbunya tidak kosong. Karena di dalam qolbu itu Allah SWT sudah menempatkan potensi-potensi dasar spiritual (fithrah), bibit iman, moralitas, ilmu dan kemerdekaan.

Jadi intinya, ada dua kategori qolbu dalam diri manusia.

1. Qolbu jasmani, yaitu hati manusia. Ada hadits tentang qolbu yang sangat populer di masyarakat, sering diucapkan oleh para ustadz dan muballigh dalam ceramah-ceramah mereka. Tapi sayangnya orang kurang cermat memahami makna qolbu pada hadits ini. Abu $\mathrm{Nu}$ `aym menceritakan bahwa Rasulullah s.a.w. berkata: "Sesungguhnya di dalam jasad ada sebongkah daging; jika ia baik maka baiklah jasad seluruhnya, jika ia rusak maka rusaklah jasad seluruhnya; bongkahan daging itu adalah qolbu". (HR. Bukhori). Dalam hadits tersebut jelas menyebut qolbu sebagai bongkahan daging (benda fisik) yang terkait langsung dengan keadaan jasad atau tubuh manusia. Bongkahan daging mana yang kalau ia sakit atau rusak maka seluruh jasad akan rusak? Bahasa Arab mengenal qolbu dalam bentuk fisik yang di dalam kamus didefinisikan sebagai 'organ yang berserat dengan otot yang fungsinya menghisap dan memompa darah, terletak di tengah dada agak miring ke kiri'. Jadi, qolbu adalah hati manusia. Dokter qolbu adalah dokter hati.

Hati adalah bongkahan daging yang kalau ia baik maka seluruh jasad akan baik atau sebaliknya kalau ia rusak maka seluruh jasad akan rusak. 
2. Qolbu ruhani, yaitu hatinurani. Ada juga jenis qolbu yang kedua, sebagaimana digambarkan dalam hadits berikut: "Sesungguhnya orang beriman itu, kalau berdosa, maka akan terbentuk bercak hitam di qolbunya”. (HR Ibnu Majah). Jadi kalau banyak dosa qolbu akan dipenuhi oleh bercak-bercak hitam, bahkan keseluruhan qolbu bisa jadi menghitam. Apakah para penjahat hatinya hitam? Apakah para koruptor hatinya hitam? Tanyakanlah kepada para dokter bedah hati, apakah hati orang-orang jahat berwarna hitam? Mereka akan katakan tak ada hati yang menghitam karena kejahatan dan kemaksiatan yang dibuat.

Lalu apa maksud hadits Nabi di atas? Qolbu yang dimaksud dalam hadits itu adalah qolbu ruhani. Ruh (jiwa) memiliki inti, itulah qolbu. Karena ruh (jiwa) adalah wujud yang tidak dapat dilihat secara visual maka qolbu yang menjadi inti (sentral) ruh ini pun qolbu yang tidak kasat mata. Dalam bahasa Indonesia 'qolbu ruhani' disebut dengan 'hatinurani'. Mungkin karena dianggap terlalu panjang dan menyulitkan dalam pembicaraan, maka orang sering menyingkatnya menjadi 'hati' saja. Padahal ada perbedaan besar antara'hati' dengan 'hatinurani' sebagaimana berbedanya 'mata' dengan 'mata kaki'.

Rupanya, istilah qolbu mirip dengan heart dalam bahasa Inggris, sama-sama memilki makna ganda. Heart dapat bermakna hati (misalnya heart attack, serangan hati) dapat juga bermakna hatinurani (misalnya you're always in my heart, kamu selalu hadir di hatinuraniku). Maka apabila mendengar perbincangan tentang qolbu perhatikanlah konteksnya. Kalau yang berbicara adalah dokter medis, tentu qolbu yang diucapkannya lebih bermakna hati. Tapi bila dikaitkan dengan perbincangan tentang moral, iman atau spiritualitas, maka maknanya lebih mengarah pada hatinurani yang wujudnya ruhaniah.

Adapun ungkapan "Qolbu orang yang berdosa akan menghitam.Ungkapan 'menghitam' di sini adalah ungkapan perumpamaan (majazi, metaphoric) bukan ungkapan sesungguhnya (haqiqi). Namun bukan berarti karena dosa tak kan nampak bekas-bekas fisiknya lalu kita akan seenaknya saja berbuat dosa. Na'udzubillah min dzalik...,". Dari sini kita akan menghindarkan dari penyakit-penyakit hati, tentunya berkaitan atas perbuatan yang menyebabkan dosa dan maksiat yang merupakan juga sebagai penghalang seseorang untuk dapat merasakan nikmatnya bertasawuf, diantaranya adalah;

\section{Iri Hati}

Iri hati adalah suatu sifat yang tidak senang akan karunia dan rahmat yang didapat oleh orang lain dan cenderung berusaha untuk menyainginya. Iri hati yang diperbolehkan dalam ajaran islam adalah iri dalam hal berbuat kebajikan, seperti iri untuk menjadi pintar agar dapat menyebarkan ilmunya di kemudian hari. Atau iri untuk membelanjakan harta di jalan kebenaran.

2. Dengki

Dengki adalah sikap tidak senang melihat orang lain bahagia dan berusaha untuk menghilangkan nikmat tersebut. Sifat ini sangat berbahaya karena tidak ada orang yang suka dengan orang yang memiliki sifat seperti ini. 


\section{Hasut/Hasud/Provokasi}

Hasud adalah suatu sifat yang ingin selalu berusaha mempengaruhi orang lain agar amarah/ marah orang tersebut meluap dengan tujuan agar dapat memecah belah persatuan dan tali persaudaraan agar timbul permusuhan dan kebencian antar sesama.

\section{Fitnah}

Fitnah lebih kejam dari pembunuhan adalah suatu kegiatan menjelek-jelekkan, menodai, merusak, menipu, membohongi seseorang agar menimbulkan permusuhan sehingga dapat berkembang menjadi tindak kriminal pada orang lain tanpa bukti yang kuat.

5. Buruk Sangka

Buruk sangka adalah sifat yang curiga atau menyangka orang lain berbuat buruk tanpa disertai bukti yang jelas.

\section{Khianat/Hianat}

Hianat adalah sikap tidak bertanggungjawab atau mangkir atas amanat atau kepercayaan yang telah dilimpahkan kepadanya. Khianat biasanya disertai bohong dengan mengobral janji. Khianat adalah ciri-ciri orang munafik. Orang yang telah berkhianat akan dibenci orang disekitarnya dan kemungkinan besar tidak akan dipercaya lagi untuk mengemban suatu tanggung jawab di kemudian hari. Dan masih ada sifat-sifat madhmumah lainnya.

Dari sini akan muncul dalam benak kita bagaimana cara mengatasi keburukan keburukan tersebut.

\section{Bagaimana cara membersihkan hati dari berbagai macam bentuk penyakit hati?}

Cara mengatasinya,

Pertama, bertaqarub kepada Allah melalui thariqat. Mengganti sifat-sifat yang kurang baik, yang melekat dihati dengan sifat-sifat yang baik, yang senantiasa mengajak kita bertaqarub kepada Allah Swt.

Kedua, kita berusaha menganti ukiran-ukiran yang buruk dalam hati kita dengan ukiran-ukiran yang indah, dengan cara berusaha menjalankan perintah Allah Swt. dan sunnah Baginda Nabi Saw.. Kemudian mendekatkan diri kita pada ulama, menghadiri ta'lim-ta'lim mereka. Karena duduk bersama para alim ulama menimbulkan daya tarik tersendiri bagi kita untuk lebih mendekatkan diri kita kepada Allah Swt. Syekh Abdul Qadir Jailani menasehatkan agar melihat diri dengan pandangan yang penuh kasih dan cinta, "Jadikan al-Kitab dan Sunnah di depan mata, lihatlah keduanya lalu amalkan. Jangan menentang sehingga tidak melaksanakan apa yang dibawanya". ${ }^{10}$

Kita telah tahu bahwa manusia itu tempatnya kekurangan. Siapapun mempunyai sifat kekurangan. Mari kita sama-sama belajar mengurangi (bukan menutup-nutupi) kekurangan yang ada pada diri kita masing-masing dengan cara berdzikir karena dapat menenangkan hati.

10 Said bin Musfir Al-Qahthani, Buku Putih Syaikh Abdul Qadir Al-Jailani, cet. ke-2, Jakarta: Darul Falah, 1425, hlm. 490 
Jika hati kita tenang, insyaallah, kita akan lebih mudah mengndalikan keinginan kita untuk berbuat maksiat.

Para sufi telah sepakat bahwa satu-satunya jalan untuk mencapai penyaksian Tuhan (musyahadah) adalah dengan kesucian jiwa. Hati manusia merupakan refleksi dzat Tuhan yang suci, dan karena itu hati manusia harus mencapai tingkat kesucian dan kesempurnaan. Untuk mencapai hal itu setiap muslim haruslah memiliki semangat dan ketekunan yang kontinu untuk dapat sampai dan memperoleh hati yang bening, bersih dan selamat (qolbun salimun). Menurut Imam Abu Hamid al-Ghazali, kemuliaan dan keutamaan manusia terletak pada kesiapan manusia untuk mengenal (ma'rifah) Allah sang Pencipta. Karena pengenalan manusia kepada Allah itulah manusia memperoleh keindahan, kesempurnaan dan kebanggaan hidup di dunia, dan kelak di akhirat ia akan memperoleh apa yang dijanjikan oleh-Nya. ${ }^{11}$

Dalam pandangan al-Ghazali, pengenalan manusia terhadap dzat-Nya (márifatullah), adalah melalui hatinya. Hatilah yang dapat mengenal-Nya dan ia pula yang dapat mendekatkan manusia kepada-Nya. Hati juga dapat berinteraksi dengan Allah dan selalu berjalan menuju kepada-Nya. Hati merupakan media penyingkap apa yang berada di sisi-Nya serta yang dimiliki-Nya. Fungsi dari semua anggota tubuh manusia tidaklah lebih dari sekedar pengikut atau pembantu hati dalam upaya menuju kepada-Nya. Hati akan memperoleh kemenangan dan merasakan kesenangan jika selalu dekat dengan Allah sepanjang manusia menjaga kebersihannya. Dalam keadaan lain hati akan menderita dan hilang harapannya jika ia dalam keadaan kotor dan berlumuran najis. Ketaatan dan kemungkaran kepada Allah adalah tingkah laku hati yang terefleksi dalam perbuatan lahir. Kegelapan dan terangnya hati akan menampakkan bekasnya dalam bentuk amal perbuatan baik dan buruk, seperti halnya setiap gelas akan memancarkan apa yang ada di dalamnya. ${ }^{12}$ (Imam Al-Ghazali terjemahan Musthofa Bisri \& Achmad Frenk, 2002: 80)

Jika manusia telah mengenal hatinya, berarti dia telah mengenal dirinya. Dan apabila seseorang telah mengenal dirinya sendiri, maka ia telah mengenal Tuhannya. Dan ketika Allah SWT bersemayam di antara diri dan hati seseorang agar ia dapat menyaksikan-Nya, dapat mengenal sifat-sifat-Nya, mengenal gerak-gerik hati mereka yang berada dikekuasaan-Nya, maka sampailah manusia kepada rasa yang akan mengantarkannya kepada kecintaan dan kerinduan yang begitu besar kepada-Nya.

\section{E. Analisa}

Kehidupan beragama memang tidak cukup diisi dengan pemenuhan atas kaidah-kaidah hukum syariah semata. Kekayaan dan pendalaman pada ranah aqidah yang terejawantahkan dalam kajian ilmu kalam juga butuh perhatian serius oleh seluruh muslim. Dan mempelajari keduanya belum terasa lengkap jika tidak disempurnakan dengan membangun akhlakul karimah

11 Imam Al-Ghazali terjemahan Musthofa Bisri \& Achmad Frenk, Manajemen Hati, cet. Ke-2, Surabaya :AlIkhlas, 2002, hlm. 78

12 Imam Al-Ghazali terjemahan Musthofa Bisri \& Achmad Frenk, Manajemen Hati, cet. Ke-2, Surabaya :AlIkhlas, 2002, hlm. 80 
yang akan membentuk watak muslim menjadi sempurna (insanul kamil).

Ketenangan jiwa ataupun kebahagiaan hidup tidak dapat diraih tanpa menghilangkan gangguan-gangguan yang kemungkinan dapat menghambat proses tazkiyyah al-nafs yang akan berlangsung. Gangguan itu biasanya lahir dari sikap rasa berdosa, bersalah atau rasa dendam. Islam menyarankan umatnya supaya tidak terlalu memikirkan tentang dosa. Ini adalah karena psikologi orang yang berbuat dosa akan merasa gelisah dan cemas selama merasa berdosa itu berada dalam dirinya

Bagaimana kita bisa mengatur qolbu dalam diri kita sendiri sehingga mampu merasakan kenikmatan bertasawuf. Semisal memakai baju dengan tangan kanan dahulu, lalu melepaskannya dengan tangan kiri.

Bagaimana kita masuk masjid dengan kaki kanan dahulu. Dan bagaimana membiasakan masuk kamar mandi dengan kaki kiri dulu dan keluar dengan kaki kanan. Artinya bagaimana kita mengikuti sunah-sunah Nabi. Itu sudah merupakan bagian dari tasawuf.

\section{Bukankah hal semacam itu sudah diajarkan orang tua kita sejak kecil?}

Para orang tua kita dulu sebenarnya sudah mengeterapkan tasawuf. Hanya saja hal itu tidak dikatakannya dengan memakai istilah tasawuf. Mereka terbiasa mengikuti tuntunan Rasulullah. Seperti ketika mereka menerima pemberian dengan tangan kanan, berpakaian dengan memakai tangan kanan dahulu. Mereka memang tak mengatakan, bahwa itu merupakan tuntunan Nabi SAW. Tapi mereka mengajarkan untuk langsung diterapkannya. Kini kita tahu kalau yang diajarkannya itu adalah merupakan tuntunan Nabi. Itu adalah tasawuf. Sebab tasawuf itu tak pernah terlepas dari nilai-nilai akhlaqul karimah. Sumber tasawuf itu adalah adab. Bagaimana adab kita terhadap kedua orang tua, bagaimana adab pergaulan kita dengan teman sebaya, bagaimana adab kita dengan adik-adik atau anak-anak kita. Bagaimana adab kita terhadap lingkungan kita. Termasuk ucapan kita dalam mendidik orang-orang yang ada di bawah kita. Kepada anak-anak kita yang aqil baligh, kita harus bener-bener menjaganya agar jangan sampai mengeluarkan ucapan yang kurang tepat kepada mereka. Sebab ucapan itu yang diterima dan akan hidup di jiwa anak-anak kita.

\section{Bagaimana sikap kita menanamkan rasa-rasa tasawuf di tengah-tengah lingkungan masyarakat yang sudah carut marut?}

Mampukah ketika kita berhadapan dengan lingkungan yang demikian itu? Ketika kita asikasiknya bergurau, maka berhentilah sejenak. Kita koreksi apakah ada sesuatu yang kurang pantas? Agar hal yang demikian itu tidak dicontoh atau ditiru oleh anak-anak kita. Itu sudah merupakan tasawuf. Jadi dalam rangka pembersihan hati, bisa dimulai dari hal-hal kecil semacam itu. Lalu kita tingkatkan dengan tutur sikap kita terhadap orang tua. Ketika kita makan bersama orang tua. Janganlah kita menyantap lebih dahulu sebelum bapak-ibu kita memulai dulu. Janganlah kita mencuci tangan dahulu sebelum kedua orang tua kita mencuci tangannya. Makanlah dengan memakai tangan kanan. Dan jangan sampai tangan kiri turut campur kecuali itu dalam kondisi darurat. Sebab Rasulullah tak pernah makan dengan kedua tangannya sekaligus. Ini 
sudah tasawuf.

Keterbelakangan di negara Muslim termasuk di Indonesia, (misalnya dalam hal pendidikan, tindak kriminal dan kasus maraknya korupsi) sering berhubungan dengan tradisi tertentu atau budaya yang tidak selaras bahkan dapat pula bertentangan dengan ajaran Islam itu sendiri, situasi seperti ini tentu tak dapat diatribusikan kepada ajaran Islam. Walaupun demikian umat Islam tak perlu merasa takut untuk memberi jawaban terhadap tantangan global dengan formulasi interpretasi ajaran agama yang lebih dapat menjawab tantangan zaman, lebih terbuka menerima kritik dan yang penting adalah tetap dalam koridor al-Qur'an dan sunnah Nabi Muhammad SAW.

Bagi kaum muslimin tak ada jalan lain kecuali memperkuat keimanan dan ketaqwaan kepada Allah SWT dengan jalan tasawuf, pada saat godaan begitu besar dalam hal mempertahankan nilai-nilai dengan tidak menghalalkan segala cara sekalipun dalam keadaan krisis ekonomi, krisis kepercayaan dan krisis spiritual. Bukan hanya itu, di negara maju dan modern sekalipun yang situasi ekonomi, pendidikan dan kesejahteraannya dalam keadaan sebaliknya dibanding dengan dunia Muslim, justru kecendrungan terhadap spiritual terutama spiritual Islam/sufistik nampak menguat dari waktu ke waktu.

Kecenderungan terhadap spiritualitas Islam, baik yang terikat secara formal dalam konteks tarekat misalnya, maupun yang non-formal, masih akan terus berlangsung, baik di daerah pedesaan maupun perkotaan, baik oleh rakyat biasa ataupun oleh pejabat dan petinggi negara. Apalagi ketika masyarakat sudah mulai merasa jenuh dengan kehidupan hedonistis di satu sisi, ataupun kehampaan dan kegersangan hati dari ketergantungan kepada yang transenden menjadikan keperluan terhadap dunia spiritual menjadi semakin kuat.

Meskipun tidak dilarang orang mencari kekayaan yang banyak, namun Syekh Abdul Wahab mengingatkan bahwa orang yang memiliki harta kekayaan akan disenangi oleh pengintai yang ingin mengambil hartanya. Akibat dari semua ini, hidup akan merasa terbelenggu dengan kekayaan dan kemewahan karena waktu tersita untuk menjaga dan merawatnya. Kondisi ini sesungguhnya berawal dari diri yang tidak dapat mengendalikan keinginan hawa nafsu. Dingatkannya, jika tidak bersungguh-sungguh melawan dan menolak keinginan hawa nafsu, maka bersiaplah untuk "menyesal di kemudian harinya".

Jikalau peti banyak isinya

Banyak pencuri ingin mengambilnya

Bersungguh-sungguh kita melawannya

Jangan menyesal kemudian harinya ${ }^{13}$

\section{Apakah hawa nafsu juga menjadi penghalang manusia untuk merasakan tasawuf?}

Ketika seseorang tidak lagi mampu membayangkan dan merasakan akhir dari apa yang bakal terjadi dikemudian hari, yang pada akhirnya mendorongnya untuk bekerja keras berdasarkan apa yang ia bayangkan itu, maka pada hakekatnya ia telah mempersiapkan sebuah pesta kepahitan

13 Syekh Abdul Wahab, Syair Sindiran, diedit oleh Syekh Haji Tajudin, Langkat: Babussalam, 1986, hlm. 3 
di masa yang akan datang. Orang seperti ini tidak saja bisa disebut ceroboh, Rasulullah bahkan menjulukinya "Orang-orang lemah "al-ajiz" yang tidak memiliki kecerdasan", atau "Orangorang yang kekuatan logikanya tidak lagi berfungsi karena ditutup oleh hawa nafsunya". Mari kita baca pesan Rasul kita ini dengan seksama: "Al-kayyisu man dana nafsahu ma'amila lima ba'dal mauti, wal ajizu man atba'a nafsahu hawaha, tsumma tamanna 'alallah" (H.R. Tirmidzi dan Ibnu Majah).

Disini Rasul kita menengarai bahwa pangkal dari segala kebodohan ini adalah hawa nafsu, ia bagaikan preman yang bila menguat akan berkuasa dan meluluh lantakkan segalanya, termasuk di dalamnya kekuatan logika.

Diantara Langkah-langkah untuk merasakan tasawuf, hemat penulis adalah ada beberapa hal yang harus di lakukan, yaitu:

\section{Taubat}

Adapun pengertian taubat oleh Dzun Nun Al-Mishri dikelompokkan pada tiga tingkatan, yaitu;

a. Orang yang bertaubat dari dosa dan keburukannya.

b. Orang yang bertaubat dari kelalaian dan kealfaan mengingat Allah

c. Orang yang bertaubat karena memandang kebaikan dan ketaatannya.

Selanjutnya, setelah pada tingkatan taubat, dalam penyempurnaannya membutuhkan ketekunan, dedikasi dan disiplin. Tiga prinsip tasawuf adalah kunci maju menuju tingkatan yang lebih baik, lebih halus, dengan tiga prinsip sebagai berikut:

1) Zuhud; menjauhkan dunia ini agar terhindar dari hukuman di akhirat. Dalam zuhud ini orang berada pada tingkatan yang tinggi ia tidak akan memandang segala sesuatu, kecuali Allah.

2) Fakir (Faqr) adalah dapat sebagai kekurangan harta yang diperlukan seseorang dalam menjalani kehidupan didunia. Sikap faqr menjadi penting dimiliki oleh orang sedang berjalan menuju Allah.

3) Sabar (ash-shabar). Kesabaran jika dipandang sebagai pengekangan tuntutan nafsu dan amarah, dinamakan sebagai sabar jiwa (shabr an-nafsi). Sedangkan menahan terhadap penyakit fisik disebut sebagai sabar badani (ash-shabr al badani) kesabaran jiwa sangat dibutuhkan dalam berbagai aspek seperti untuk menahan nafsu makan dan seks yang berlebihan. ${ }^{14}$

\section{Dzikir}

Dzikir dapat dilakukan dengan dua cara, dengan cara lisan dan qolbu. Dalam dzikir lisan adalah dzikir mengucapkan lafal-lafal, dzikir tertentu, baik dengan suara keras maupun dengan suara yang hanya dapat didengar oleh yang berdzikir itu sendiri.

Adapun lafal dalam dzikir lisan diantaranya sebagai berikut:

a. Tahmid, yaitu mengucapkan al-hamdulillah (segala puji kepunyaan Allah)

14 Imam Al-Ghazali, Ihya'Ulumuddin Jilid IV, Bandung: Mizan Media Utama, 1991, hlm. 322 
b. Tasbih, yaitu mengucapkan subhanallah (maha suci Allah)

c. Takbir, yaitu mengucapkan Allahu Akbar (Allah maha besar)

d. Tahlil, yaitu mengucapkan la ilaha ill Allah (tiada Tuhan selain Allah)

e. Basmallah, (dengan nama Allah yang Maha Pengasih lagi Maha Penyayang)

f. Istighfar, yaitu mengucapkan Astaghfirullah (aku memohon ampun kepada Allah)

g. Hawqalah, yaitu mengucapkan La hawla walaa quwata illa billa (tiada daya dan tiada kekuatan kecuali daya dan kekuatan dari Allah)

h. Lafal dzikir berupa ayat-ayat Al-Qur'an baik keseluruhan maupun sebagiannya, satu surat maupun berupa ayat tertentu. ${ }^{15}$

Cara yang kedua: dengan cara qolbu, adalah dzikir tersembunyi, di dalam hati, tanpa suara dan kata-kata. Dzikir ini hanya memenuhi qolbu dengan kesadaran yang sangat dekat dengan Allah. Seirama dengan detak jantung serta mengikuti keluar masuknya nafas. Dzikir qolbu yaitu mengingat Allah dengan hati ketika merenungkan keindahan dan keagungan Allah dalam relung hati yang terdalam. Dalam dzikir qolbu, mempunyai efek-efeknya sendiri yang mencerahkan diri dan dapat menciptakan kerinduan kepada Allah, membina kecintaan kepada Allah dalam hati, melahirkan perenungan.

Banyak sekali perbedaan posisi atau cara berdzikir dilakukan oleh para sufi. Tetapi inti dari berdzikir itu sama menuju kepada Allah SWT. ${ }^{16}$

Kalau terus menerus melakukan praktik dzikir, akan menaruh perhatian pada proses berfikir tak ada ujung pangkalnya yang terus berlangsung dengan memusatkan perhatian pada satu titik dan berkonsentrasi, yang akan bergema dalam hati. Hati merupakan wahana kesadaran dan memiliki lapisan-lapisan, bila dilakukan terus-menerus, dzikir akan masuk menembus lapisanlapisannya hati, dan hati akan menjadi bersih cemerlang, yang akan membawa pada sifat-sifat yang dikehendaki Allah, serta dapat terhindar dari penyakit psikis. ${ }^{17}$

1. Takut dan Berharap, merasa takut kepada Allah akan murka dan siksaan-Nya jika melakukan hal-hal yang tercela. Sedangkan berharap berarti memiliki harapan yang besar atau optimis atas ampunan, kemurahan, rahmat, pertolongan dan kasih sayang Allah.

2. Tauhid dan Tawakkal, yang berfungsi sebagai pengobatan atas penyakit-penyakit hati,pencegahan, pembinaan hati dan jiwa dengan jalan menuju kepada Allah.

3. Kasih sayang, di lengkapi dengan rasa rindu, dan ridha, dapat mendorong seseorang untk bersungguh-sungguh mentaati Allah dan mendekatkan diri kepada-Nya.

4. Niat, dengan ikhlas, dan benar, fungsinya agar manusia mampu bersikap jujur terhadap diri sendiri dan orang lain.

5. Al-Muraqabah dan Muhasabah. Muraqabah adalah mawas diri kepada Allah dengan mendekatkan diri kepada-Nya. Muhasabah adalah meyakini bahwa Allah mengetahui segala pikiran, perbuatan dan rahasia dalam hati yang seseorang menjadi hormat, takut dan tunduk

15 Qomarudin, Zikir Sufi, Jakarta: PT. Serambi Ilmu Semesta, 2000, hlm. 173

16 Qomarudin, Zikir Sufi, Jakarta: PT. Serambi Ilmu Semesta, 2000, hlm. 176

17 Amin Syukur, Dzikir dan Kesehatan, Seminar Sufi Healing dan Prana, Semarang: IAIN Walisongo, 2002, hlm. 2 
kepada Allah dengan mengoreksi dan mengintropeksi diri.

6. Tafakur adalah sebagai penyelamat dan penerang jiwa dalam berfikir. Dalam bertafakur seseorang menghadirkan jiwa mempergunakan akalnya untuk memikirkan dirinya, makhluk lain, dan keagungan Allah dengan berfikir yang positif dan benar.

7. Dzikrul Maut, yaitu dengan mengingat kematian seseorang akan berfikir tentang kebahagiaan dan kesengsaraan hidup di akhirat. ${ }^{18}$

Seorang mukmin sesungguhnya mempunyai tujuan yang baik di semua perilakunya. Ia bekerja di dunia bukan untuk dunia, melainkan membangun dunia untuk akhirat. Jika ia melakukan yang lain, tujuannya adalah untuk keluarga, fakir miskin dan apa yang seharusnya ia perlukan dalam kehidupan. Dia melakukan semua itu supaya kelak diberikan pahala di akhirat. Dia tidak menuntut apapun di dunia karena di akhirat pun juga banyak tuntutannya.

\section{F. Kesimpulan}

1. Jalan utama menuju kebersihan jiwa dan kesucian hati ini, adalah sebuah proses yang disebut dengan "Ibadah-ibadah hati". Ibadah-ibadah zahir memang sangat penting dan menentukan bagi keselamatan manusia di dunia dan di akherat, namun demikian "ibadah-ibadah hati" lebih menentuka lagi, karena ibadah-ibadah zahir tersebut walau sudah terpenuhi syarat dan rukunnya secara sempurna, tetap tidak akan diterima oleh Allah jika tidak dibangun diatas ibadah hati yang benar dan sempurna. Sebagai contoh: shalat yang dilaksanakan dengan syarat dan rukun yang sempurna tidak akan diterima jika dilakukan tanpa keiikhlasan yang sempurna karena Allah. Pengalaman kerohanian ini biasanya di ukur dengan rasa (dzawq) yang tentu saja sangat bersifat personal karena setiap individu merasakan pengalaman yang dipastikan tidak akan pernah sama dengan yang lain.

2. Ketenangan jiwa ataupun kebahagiaan hidup tidak dapat diraih tanpa menghilangkan gangguan-gangguan yang berkemungkinan menghambat proses tazkiyyah al-nafs berlangsung. Gangguan itu biasanya lahir dari sikap rasa berdosa, bersalah atau rasa dendam. Islam menyarankan umatnya supaya tidak terlalu memikirkan tentang dosa. Ini adalah karena psikologi orang yang berbuat dosa akan merasa gelisah dan cemas selama merasa berdosa itu berada dalam dirinya.

3. Dzikir qolbu yaitu mengingat Allah dengan hati ketika merenungkan keindahan dan keagungan Allah dalam relung hati yang terdalam. Dalam dzikir qolbu, mempunyai efekefeknya sendiri yang mencerahkan diri dan dapat menciptakan kerinduan kepada Allah, membina kecintaan kepada Allah dalam hati, melahirkan perenungan. Banyak sekali perbedaan posisi atau cara berdzikir dilakukan oleh para suf. Tetapi inti dari berdzikir itu sama menuju kepada Allah SWT. Jadi ketika qolbu itu terbuka berdzikir berarti terbukalah pintu-pintu tasawuf dalam diri manusia dan untuk merasakan nikmatnya sehingga dapat melakukan ibadah dan segala amal-amal saleh yang akan menyelamatkan manusia di dunia dan akherat. 


\section{Bibliografi}

Al-Ghazali, Imam, 1997, Risalah-Risalah Al-Ghazali, Bandung : Pustaka Hidayah.

Majid, Fakhry, 2002, Sejarah Filsafat Islam, Bandung: Mizan.

Otto, Rudolf, 1967, The Psychology of Religion, New York: McMillan.

Muslim, Abi Al-Husain, 1377 H, Shahih Muslim, juz III, Mesir: Musthafa al-Baby al Halaby wa Auladih.

Wahab, Syekh Abdul, 1986, Syair Sindiran, diedit oleh Syekh Haji Tajudin, Langkat: Babussalam.

Al-Qahthani, Said bin Musfir, 1425 H, Buku Putih Syaikh Abdul Qadir Al-Jailani, cet. ke-2, Jakarta: Darul Falah.

Hawwa, Said, 1996, Jalan Ruhani, cet. Ke-4, Bandung : Mizan.

Al-Ghazali, Imam, 1996, Munqidz min al-Dlalal, dalam Majmuah Rasail, Beirut: Dar al-Fikr.

Al-Ghazali, Imam, 2002, Manajemen Hati, terjemahan KH. A. Musthofa Bisri \& Achmad Frenk, cet. Ke-2, Surabaya :Al-Ikhlas.

Syukur,Amin dan Fatimah Usman, 2004, Insan Kamil Kontemporer (Paket Pelatihan Seni Menata Hati (SMHI), CV., Semarang: Bima Sejati.

Al-Ghazali, Imam, 1991, Ihya'Ulumuddin Jilid IV, Bandung: Mizan Media Utama.

Qomaruddin, 2000, Zikir Sufi, Jakarta: PT. Serambi Ilmu Semesta.

Syukur, Amin, 2002, Dzikir dan Kesehatan, Seminar Sufi Healing dan Prana, Semarang: IAIN Walisongo.

Jaelani, Drs. AF, 1997, Penyucian Jiwa Dan Kesehatan Mental, Jakarta: Amza. 